\title{
Chromosomal Population Analysis \\ In Cows Descendant from a Translocation Heterozygote A.I. Bull in Baviera
}

\author{
M. MENKEN \\ Aus dem Lehrstuhl für Tierzucht der Technischen Universität Munchen, \\ Freising-Weihenstephan, R.F.A.
}

\begin{abstract}
Between the many types of chromosomal aberrations, the translocations of centric fusion type are very interesting, because they result in change of the form and number of chromosomes of one given species. These aberrations were found in several domesticated animals. In domestic cattle ( $B$. taurus) there are at least four different types of centric fusions distributed among different breeds and in various countries. The most frequent centric fusion is the $1 / 29$. This aberration is found with greater frequency between the best animals used for reproduction. Wether the different types of centric fusion have a positive or negative effect on zootechnical trails is yet unclear, and so also its origin. In the present work a centric fusion of the I/29 type in a German Brown Cattle from Bavaria is described. The centric fusion was found in a very good A.I. bull, and before it was known that it was a I/29 translocation earrier his semen was used in round 30 ooo inseminations. The material studied consists in more than 4 oo cows who finished at least their first lactation. The parameters studied does not show any important deviations as expected for a normal good reproducer.
\end{abstract}

\section{Results of Orcein, C- and G-banding techniques in the Gayal (Bibos frontalis) and its crossbreds with European cattle (Bos taurus typicus)}

\author{
H. FISCHER and E. SCHEURMANN
}

Institut fur Tropische, Veterinarmedizin, Wilhelmsirasse 15, Giessen 63, R.F.A.

'The behaviour of chromosomes in crossbreds of the Gayal or Mithan (Bibos frontalis) with German Blackpied cattle (Bos taurus typicus) has been investigated in two successive crossbred generations. Bibos frontalis has a karyotype of $2 n=58$ (2 submetacentric and 54 acrocentric autosoms, $\mathrm{XX}$ and $\mathrm{XY}$ submetacentric), Bos taurus typicus karyotype is $2 n=60$ ( 58 acrocentric autosoms, $\mathrm{XX}$ and $\mathrm{XY}$ submetacentric).

$\mathrm{F}_{1}$ crossbreds have $2 n=59, \mathrm{XX}$ or $59, \mathrm{XY} .56$ autosoms are acrocentric, one unpaired autosom is submetacentric and gonosoms are submetacentric. Two $F_{1}$ females produced a calf each from German Blackpied bulls. $\mathbf{F}_{2}$ crossbred females (25 p. cent Gayal 75 p. cent Blackpied) exhibit karyotypes of $2 n=59, \mathrm{XX}$ or $2 n=60, \mathrm{XX}$. Various banding methods are used to compare banding patterns of the $F_{1}$ and $F_{2}$ crossbreds with those of the $P$ generation.

A $F_{1}$ bull from a Gayal cow and a Blackpied bull is being reared and tested andrologically.

\section{Cytogenetic Studies on Inherited Neurofibromatosis in Calves}

L. LOJDA and S. SLANINA

Veterinary Research Institute, Brno, Tchekoslovaquie

This report is concerned with the mass incidence of congenital neurofibromatosis of the skin in calves born in one area during a three-year period. The clinical picture consisted of unilateral progressive tumours on the face, and its incidence was limited to the progeny of one bull. Extensive laboratory examinations including virological examination and bioassay yielded negative results. Cytogenetic examination could be made on only 8 affected calves and 4 of the dams, 
since the remaining calves and the sire had been slaughtered before our examination began.

Of the 8 calves examined four showed $\mathbf{I} / 29$ translocation in the heterozygous state, one animal showed this translocation in the homozygous state and the remaining three calves were free of this aberration. None of the dams showed translocation. It is of interest to note that some quantitative cytogenetic data (counts of cells with breaks or gaps) obtained for the calves corresponded to those obtained for their dams.

The cytogenetic finding's are interpreted as indicating random association of two inherited ealth disorders.

\title{
R-Banding studies in Bos taurus and Ovis aries
}

\section{KOULISCHER and J. DIVOY}

\author{
29 bis, Allée des Templiers, \\ 6270 Loverval (Belgique)
}

The chromosomes of Bos taurus and Ovis aries have been studied using the R-banding technique (DUTRILLAUX and LEJEUNE, I97I). The banding pattern obtained allows an accurate identification of chromosome pairs, including those of Ovis aries involved in the centromeric fusion.

But the most striking observation concerns the centromeres. All centromeres appear darkly stained, just as if $\mathrm{C}$ - banding had been used. As a control, human chromosomes were stained in identical conditions, in the same containers than the Bovoidea chromosomes: the usual R-banding pattern of Man was observed. This shows first that the centromeric staining of Bos taurus and Ovis aries is not an artefact, second that very likely it is not constitutive heterochomatin that has been detected.

Should $R$ and $C$-banding be linked with the nature of the chromosomal DNA (eu - or heterochromatin, repetitive short or long DNA sequences, etc.), the present observation is suggestive of the presence of more than one kind of DNA at the centromeric region of the Bovoidea.

\section{Fertility of sires born as dizygotic twins and sex ratio in their progeny groups}

\section{GUSTAVSSON}

\author{
Department of Animal Genetics, Nutrition and Hygiene, \\ Royal Veterinary College, $H V C, S-750$ o7 Uppsala 7, Sweden
}

Often reduced fertility and deviating sex ratios in progeny groups have been reported for bulls born as dizygotic twins. Fxperience from the last 20 years' of A.I. work within the Swedish Red and White cattle breed is reported. A total of 33 bulls born as dizygotic twins and divided into three groups according to sampling method, were investigated with respect to semen quality and quantity, conception rate at first service, non-return (NR) rates of 28 and 56 days, and sex ratio of progeny groups. The information available neither point to deviating semen characteristics and reduced fertility of the bulls nor to deviating sex ratios of the progeny groups. Therefore the diagnosis " born as a twin " has hitherto been omitted from consideration in breeding work of cattle in Sweden.

\section{Disparition des cellules germinales et déroulement anormal de la méiose chez les fotus de veau freemartins}

\author{
J. PRÉPIN, B. VIGIER et A. JOST \\ Physiologie Comparée, 9, quai St-Bernard, 75 Paris-5e, France
}

L'effet freemartin se manifeste au niveau des glandes génitales vers $49-52$ j par un arrêt de leur croissance et par un ralentissement très marqué de l'augmentation du nombre des cellules germinales par rapport aux témoins. Le nombre des cellules germinales décroît à partir de 7o $\mathrm{j}$ et devient très faible à I $50 \mathrm{j}$. 